\title{
Physical and mechanical properties of the wood of coffee trunks and branches
}

\author{
Nara Silveira Velloso ${ }^{1}$, Ricardo Rodrigues Magalhães ${ }^{1}$, , Fábio Lúcio Santos ${ }^{1}$,

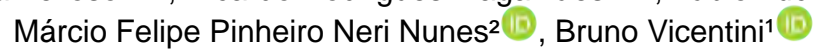

\begin{abstract}
'Universidade Federal de Lavras/UFLA, Departamento de Engenharia/DEG, Lavras, MG, Brasil
${ }^{2}$ Universidade Federal de Lavras/UFLA, Departamento de Ciência do Solo/DCS, Lavras, MG, Brasil

Contact authors: naravelloso@yahoo.com.br, ricardorm@ufla.br, fabio.santos@ufla.br, marcionerifpn17@gmail.com, bruno.vicentini@ufla.br Received in April 19, 2020 and approved in October 26, 2020
\end{abstract}

\begin{abstract}
Knowledge of the physical and mechanical properties of coffee plants is essential to the development of mechanisms that perform the harvesting of their fruits by the principle of mechanical vibrations; however, these properties have yet to be determined in the laboratory. In this context, the present study aimed to determine the mechanical and physical properties of coffee plants through tensile and compression tests by means of a universal testing machine. Elasticity modulus, Poisson's ratio, and specific mass were determined for specimens developed from the trunks and branches of 20 samples whole coffee plants, Coffea arabica variety, Catuaí Vermelho cultivar. The elasticity modulus was determined by the slope of the secant line in the elastic region of the stress-strain curve. Poisson's ratio was determined by direct measurements in regions previously marked on the specimens. The conventional specific mass was obtained by the ratio between the mass of specimens and their volume. The methodology allowed the studied properties and a database to be obtained, and they can be used as a basis for the development and operation of the mechanism used in the mechanical and semi mechanical harvesting of coffee fruits. The results obtained indicate the following values for elasticity modulus of the trunk, performed from compression tests: 1090.94 $\mathrm{MPa}$ in the longitudinal direction and $108.60 \mathrm{MPa}$ in the cross-sectional direction. For elasticity modulus of the branches, performed from tensile tests in the longitudinal direction: $507.72 \mathrm{MPa}$. For Poisson's ratio, determined by direct measurements: 0.25 for the trunk and 0.09 for the branches. And for specific mass: $1070.05 \mathrm{~kg} \cdot \mathrm{m}^{-3}$ for the trunk and $1036.33 \mathrm{~kg} \cdot \mathrm{m}^{-3}$ for the branches.
\end{abstract}

Key words: Elasticity modulus; Poisson's ratio; Specific mass; Geometrical properties.

\section{INTRODUCTION}

Brazil is the largest coffee exporter and the secondlargest consumer of coffee in the world, second only to the United States (Organização Internacional do Café - OIC 2019; Associação Brasileira da Indústria de Café - ABIC, 2017). Among the regions with the highest crop production, the state of Minas Gerais stands out and, in addition to being the main Brazilian producer of Arabica coffee, produces the highest-quality coffee (Fundação João Pinheiro - FJP, 2018).

Knowledge about the physical and mechanical properties of agricultural products is essential to the development of harvesting and postharvesting mechanisms, which are considered the costliest stages of the coffee production chain. These properties refer to the behavior of the product in various situations and request levels. The combination of a particular mechanism and the agricultural product can be achieved only when one can predict what will happen when the product is affected by daily operational factors, such as heating, cooling, traction, torsion, cutting and shear (Costa et al., 2014).

Ciro (2001) and Coelho et al. (2015) determined geometric and mechanical properties related to the elasticity of the fruit-peduncle-branch system of the coffee plant, and Carvalho, Magalhães and Santos (2016) used compression tests to determine the mechanical properties of the coffee trunk (elasticity modulus, Poisson's ratio and specific mass); these properties were used as input data to perform numerical simulations to predict the dynamic and static behavior of the coffee plant when subjected to external forces. Aristizábal, Oliveros and Alvarez (2003), worked on coffee plant trunks of different cultivars to determine the mechanical properties associated with vibration. To this end, the authors treated the coffee branches and trunk as a rectangular section beam subjected to bending in universal testing machine.

Souza et al. (2018), Tinoco et al. (2014) and Santos et al. (2015) also used mechanical properties known as the base to simulate the dynamic behavior fruit-peduncle system of the coffee and coffee branch.

Tensile and compressive tests were also performed by Villar et al. (2017), Velloso et al. (2017) and Oliveira et al. (2018) with the objective of creating a database of geometric and mechanical properties for the macaw palm crop, which, similarly to coffee, is a crop in which fruit harvest can be performed by machines that use the mechanical vibration principle (Grupioni et al., 2018).

In crops such as coffee, where the harvesting of fruits is performed by mechanical vibration, kinetic energy is transmitted to the plant or a portion of it by electrical, pneumatic, hydraulic or mechanical power sources (Coelho et al., 2015). For these purposes, knowledge of the properties related to elasticity and rigidity is important because different 
scenarios for harvesting the fruits can be predicted from the mechanical properties of the trunk and branch wood, thus justifying new investigations in the area.

In this context, the present study aimed to determine the mechanical and physical properties of coffee trunks and branches, characterizing the resistance of coffee plants, which can be used as a basis for the development and operation of machines that perform grain harvesting by the mechanical vibration principle.

\section{MATERIAL AND METHODS}

The specimens came from trunks and branches of 20 whole coffee plants, 6 years old, which had an average length of approximately $2 \mathrm{~m}$ and were of the Coffea arabica variety, Catuaí Vermelho cultivar (IAC 144).

Each plant was collected daily. Specimens prepared from the trunk and branches were tested on the same day as collection to prevent losses in their chemical composition and moisture, which could interfere with the mechanical properties. To maintain field characteristics, the specimens did not undergo any type of drying.

Thus, the specimens prepared from the trunk were composed of parts cut directly from the trunk where bark was removed, without the branches. Each specimen had an approximate length of $0.07 \mathrm{~m}$, totaling 12 to 15 specimens per plant (Figure 1). The length of the specimens was determined from previous tests of different sizes starting from longer sizes to a size where the sample could not buckle when being compressed by the machine.

Each specimen was identified according to the part of the trunk from which it was removed: lower, middle or upper thirds (Figure 2).

The specimens prepared from the branches were cut directly from the samples of coffee plants, in random parts, with an approximate length of $0.2 \mathrm{~m}$, totaling six specimens per plant, and they did not undergo any treatment. Such length was determined from the distance between the claws of the universal testing machine and the deformations present in the branches of the coffee plants (Figure 3).

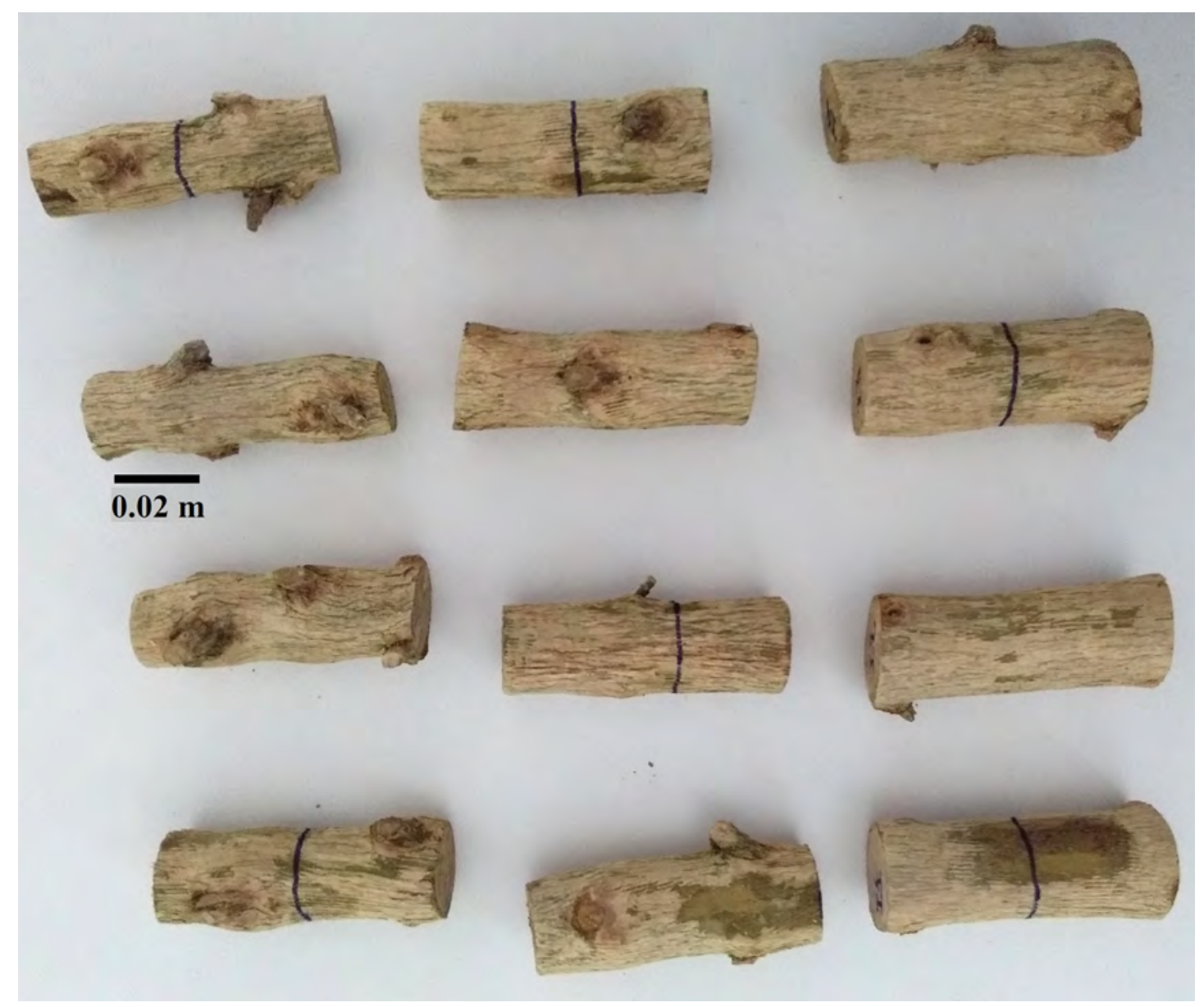

Figure 1: Specimens produced from the trunks of a coffee plant sample and which were subjected to compression tests in the universal testing machine, in parallel and perpendicular to the fibers. 


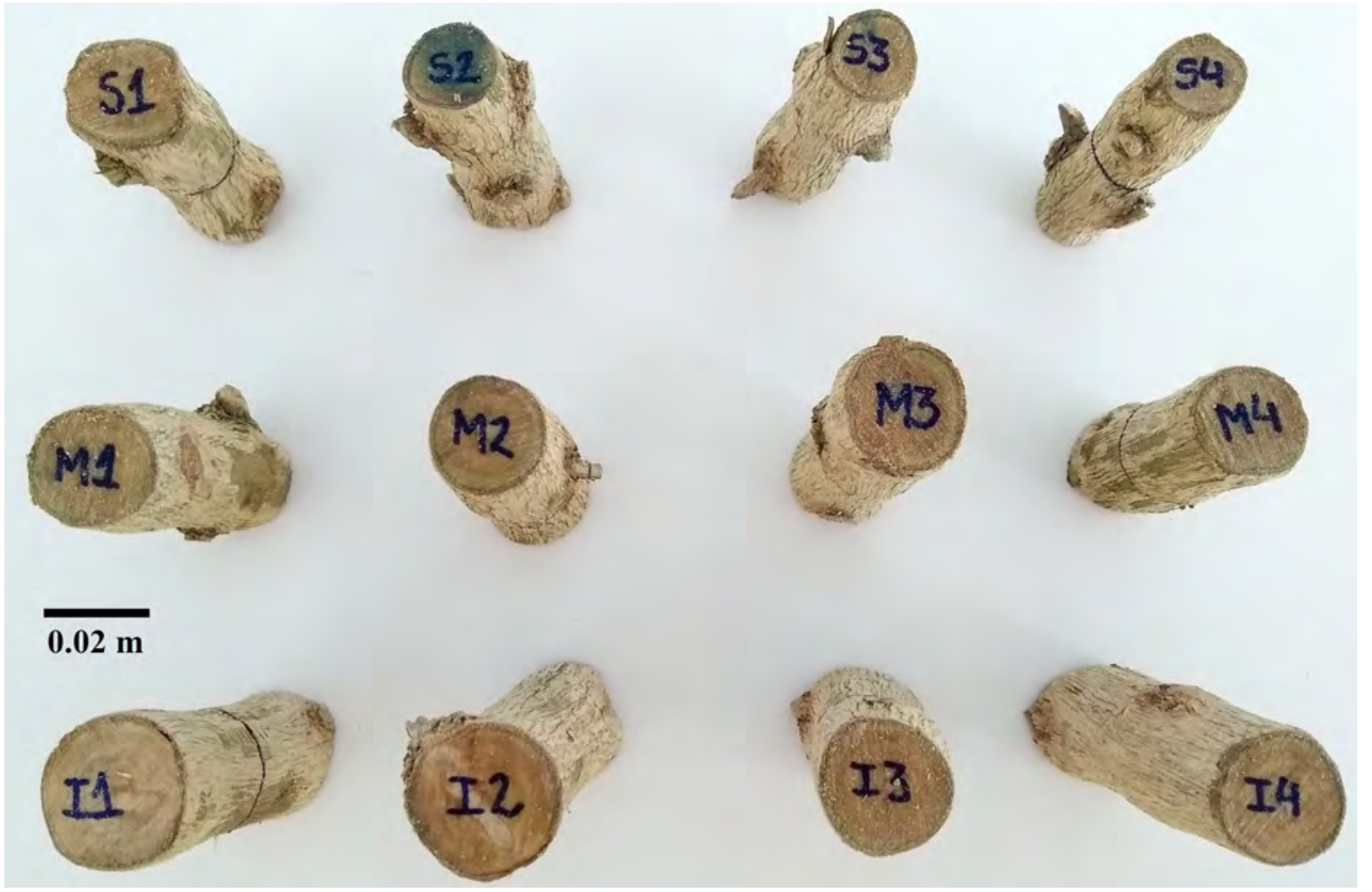

Figure 2: Identification in each specimen produced from the trunks of the coffee plants, which were subjected to compression tests in a universal testing machine, where $\mathrm{S}$ refers to the upper third, $\mathrm{M}$ to the middle third and $\mathrm{I}$ to the lower third.

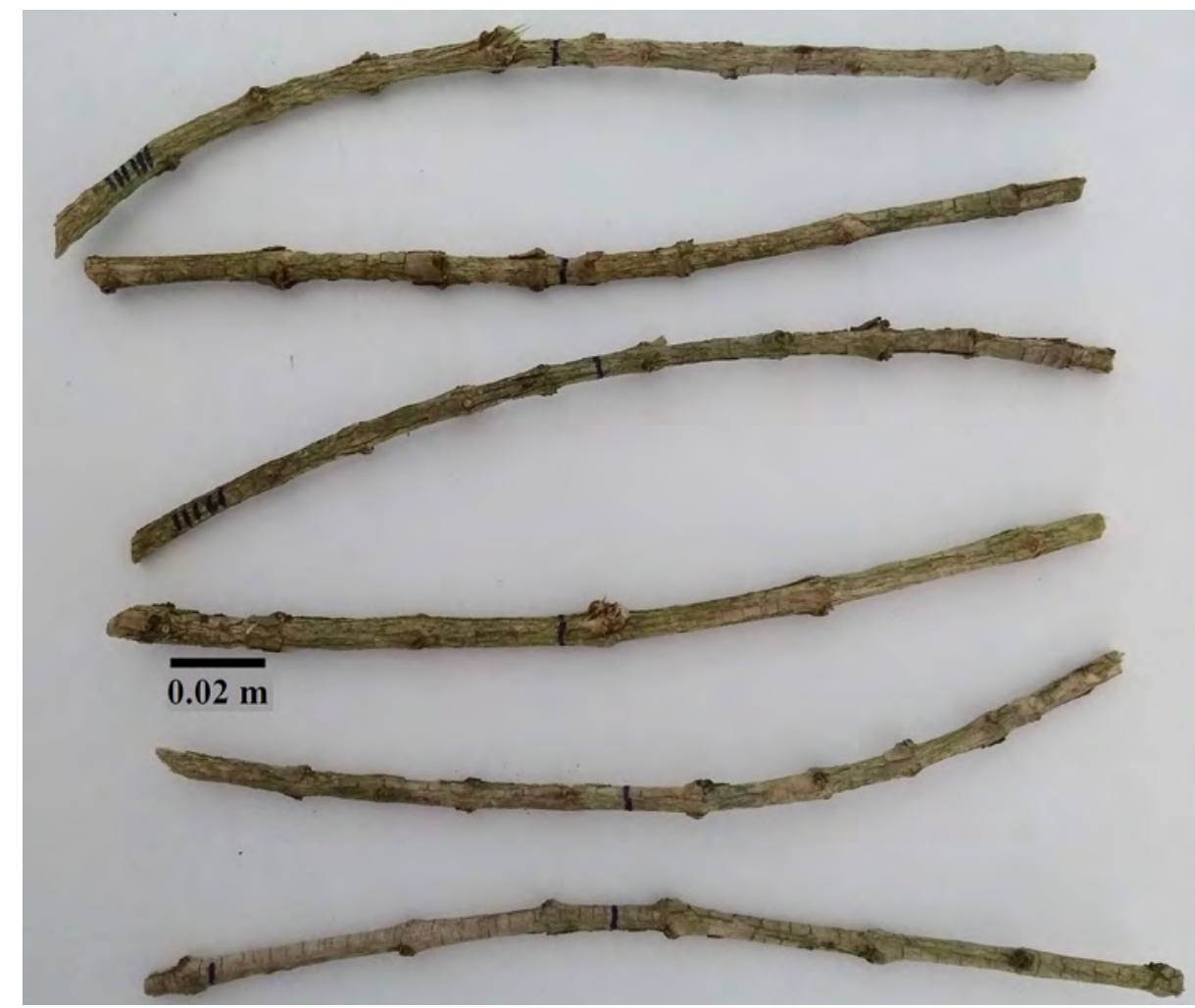

Figure 3: Specimens produced from the branches of a coffee plant sample and subjected to tensile tests, in a universal testing machine, in the direction parallel to the fibers. 


\subsection{Physical and Geometric Properties}

Each specimen had its mass determined in a $0.001 \mathrm{~g}$ precision scale, Marte brand, model AD500. Its diameters and lengths were determined with an MTX caliper, model 316119, with a $0.01 \mathrm{~mm}$ precision. The mean diameter was calculated from the average of six diameters measured at both ends and in the middle of each specimen (Table 1).

Table 1: Mean diameter values for coffee plant samples.

\begin{tabular}{|c|c|c|c|c|c|c|}
\hline \multicolumn{7}{|c|}{ Mean diameters (m) } \\
\hline Sample & $\mathbf{n}$ & Trunks & $\delta$ & $\mathbf{n}$ & Branches & $\delta$ \\
\hline 1 & 10 & 0.031 & 0.003 & 6 & 0.006 & 0.0008 \\
\hline 2 & 10 & 0.032 & 0.004 & 5 & 0.005 & 0.0002 \\
\hline 3 & 11 & 0.025 & 0.003 & 7 & 0.003 & 0.0009 \\
\hline 4 & 9 & 0.030 & 0.003 & 6 & 0.006 & 0.0008 \\
\hline 5 & 13 & 0.027 & 0.002 & 6 & 0.007 & 0.0001 \\
\hline 6 & 11 & 0.026 & 0.003 & 6 & 0.006 & 0.0003 \\
\hline 7 & 11 & 0.030 & 0.002 & 6 & 0.006 & 0.0008 \\
\hline 8 & 11 & 0.021 & 0.004 & 6 & 0.006 & 0.0011 \\
\hline 9 & 11 & 0.025 & 0.004 & 6 & 0.005 & 0.0007 \\
\hline 10 & 12 & 0.022 & 0.003 & 6 & 0.004 & 0.0005 \\
\hline 11 & 12 & 0.027 & 0.001 & 6 & 0.006 & 0.0004 \\
\hline 12 & 13 & 0.024 & 0.002 & 6 & 0.005 & 0.0007 \\
\hline 13 & 9 & 0.027 & 0.004 & 6 & 0.006 & 0.0007 \\
\hline 14 & 10 & 0.020 & 0.001 & 6 & 0.005 & 0.0007 \\
\hline 15 & 10 & 0.022 & 0.005 & 6 & 0.006 & 0.0010 \\
\hline 16 & 10 & 0.026 & 0.005 & 6 & 0.005 & 0.0012 \\
\hline 17 & 11 & 0.027 & 0.004 & 6 & 0.005 & 0.0007 \\
\hline 18 & 10 & 0.025 & 0.003 & 6 & 0.006 & 0.0005 \\
\hline 19 & 12 & 0.028 & 0.005 & 6 & 0.006 & 0.0009 \\
\hline 20 & 10 & 0.029 & 0.003 & 6 & 0.006 & 0.0006 \\
\hline
\end{tabular}

$\mathrm{n}$ : Number of specimens; $\delta$ : Standard deviation.

The volume of the specimens made from the trunks was determined by immersion in water following the recommendations of NBR 7190 (Associação Brasileira de Normas Técnicas ABNT, 1997), whereas the volume of the specimens made from the branches was approximated by the volume of a cylinder obtained from the measurements of their diameters and lengths. The conventional specific mass was obtained by the ratio between the mass of specimens and their volume (Table 2), according to the requirements of NBR 7190 (ABNT, 1997).

The specimens from the trunks were subjected to compression tests, and the specimens from the branches were subjected to tensile tests in a universal testing machine (Instron, model EMIC 23-20) equipped with a $20 \mathrm{kN}$ load cell, whose elasticity modulus and Poisson's ratios were determined, following the flowchart shown in Figure 4.

\subsection{Elasticity Modulus}

The elasticity modulus was determined by the slope of the secant line in the elastic region of the stress-strain curve (Equation 1) (Garcia; Spim; Santos, 2012).

$E=\frac{\sigma}{\varepsilon}=\frac{P \cdot L_{0}}{S_{0} \cdot \Delta L}$

where,

$E$ = elasticity modulus, $\mathrm{Pa}$;

$\sigma=$ stress, $\mathrm{Pa}$;

$\varepsilon=$ strain;

$P=$ applied load, $\mathrm{N}$;

$L_{0}=$ initial reference length (zero load), $\mathrm{m}$;

$S_{0}=$ original cross section, $\mathrm{m}^{2}$;

$\Delta L=$ elongation, $\mathrm{m}$.

The specimens made from coffee trunks underwent compression tests in two directions: parallel to the sample fibers (E) (Figure 5) and transverse to the sample fibers $\left(E_{D}\right)$ (Figure 6). The specimens made from the coffee branches were subjected to tensile tests in the direction parallel to the sample fibers (Figure 7).

The routines to control both tests were programmed in the software application Instron ${ }^{\circledR}$ Bluehill $^{\circledR}$. Each test had a speed of $0.01 \mathrm{~m} . \mathrm{min}^{-1}$ and resulted in the values of time, stress and strain, according to NBR 7190 (ABNT, 1997). With the stress and strain data how the stress-strain curves were plotted and their secant was calculated.

\subsection{Poisson's Ratio}

Poisson's ratio was determined by direct measurements in regions previously marked on the specimens (central region). The material of the specimens was considered isotropic (did not have their differences in deformations, in the different directions taken into account), and the cross-sectional and longitudinal dimensions of the specimens were measured before and after the tensile and compression tests parallel to the fibers (Rao, 2008). Variations in the dimensions allowed one to obtain Poisson's ratio (Equation 2) (Garcia; Spim; Santos, 2012).

$v=\frac{\varepsilon_{T}}{\varepsilon_{L}}$

where,

$v=$ Poisson's ratio;

$\varepsilon_{T}=$ cross-sectional variation, $\mathrm{m}$;

$\varepsilon_{L}=$ longitudinal variation, $\mathrm{m}$.

A total of 48 valid tests were considered for specimens from the trunk, and 76 valid tests were considered for specimens from the branches. The values used were between zero and 0.5 , and the outliers were excluded. 
Table 2: Mean mass and volume values for coffee plant samples.

\begin{tabular}{|c|c|c|c|c|c|c|c|c|c|c|}
\hline \multirow[b]{2}{*}{ Sample } & \multicolumn{5}{|c|}{ Trunks } & \multicolumn{5}{|c|}{ Branches } \\
\hline & $\mathbf{n}$ & Mass (kg) & $\delta$ & Volume (m³) & $\delta$ & $\mathbf{n}$ & Mass (kg) & $\delta$ & Volume (m³) & $\delta$ \\
\hline 1 & 10 & 0.057 & 0.008 & $54.30 e^{-6}$ & $7.93 e^{-6}$ & 6 & 0.007 & 0.002 & $7.72 e^{-6}$ & $1.82 e^{-6}$ \\
\hline 2 & 10 & 0.066 & 0.016 & $62.60 e^{-6}$ & $1.40 e^{-5}$ & 5 & 0.004 & 0.002 & $4.84 e^{-6}$ & $4.99 e^{-7}$ \\
\hline 3 & 11 & 0.038 & 0.007 & $36.40 e^{-6}$ & $8.24 e^{-6}$ & 7 & 0.002 & 0.001 & $2.33 e^{-6}$ & $1.23 e^{-6}$ \\
\hline 4 & 9 & 0.055 & 0.013 & $51.89 e^{-6}$ & $1.21 e^{-5}$ & 6 & 0.006 & 0.001 & $6.14 e^{-6}$ & $1.60 e^{-6}$ \\
\hline 5 & 13 & 0.044 & 0.008 & $41.31 e^{-6}$ & $7.41 e^{-6}$ & 6 & 0.007 & 0.002 & $8.15 e^{-6}$ & $2.64 e^{-6}$ \\
\hline 6 & 11 & 0.041 & 0.008 & $39.00 e^{-6}$ & $7.67 e^{-6}$ & 6 & 0.005 & 0.001 & $6.16 e^{-6}$ & $7.01 e^{-7}$ \\
\hline 7 & 11 & 0.059 & 0.011 & $54.55 e^{-6}$ & $1.01 e^{-5}$ & 6 & 0.007 & 0.001 & $6.50 e^{-6}$ & $1.53 e^{-6}$ \\
\hline 8 & 11 & 0.029 & 0.011 & $27.73 e^{-6}$ & $9.93 e^{-6}$ & 6 & 0.008 & 0.003 & $7.61 e^{-6}$ & $2.68 e^{-6}$ \\
\hline 9 & 11 & 0.037 & 0.012 & $35.55 e^{-6}$ & $1.26 e^{-5}$ & 6 & 0.004 & 0.001 & $4.53 e^{-6}$ & $1.20 e^{-6}$ \\
\hline 10 & 12 & 0.032 & 0.006 & $30.33 e^{-6}$ & $5.79 e^{-6}$ & 6 & 0.003 & 0.001 & $3.87 e^{-6}$ & $9.29 e^{-7}$ \\
\hline 11 & 12 & 0.045 & 0.005 & $42.00 e^{-6}$ & $4.55 e^{-6}$ & 6 & 0.007 & 0.001 & $7.31 e^{-6}$ & $9.07 e^{-7}$ \\
\hline 12 & 13 & 0.035 & 0.008 & $33.23 e^{-6}$ & $7.53 e^{-6}$ & 6 & 0.005 & 0.001 & $5.33 e^{-6}$ & $1.37 e^{-6}$ \\
\hline 13 & 9 & 0.046 & 0.014 & $42.89 e^{-6}$ & $1.41 e^{-5}$ & 6 & 0.007 & 0.001 & $6.57 e^{-6}$ & $1.45 e^{-6}$ \\
\hline 14 & 10 & 0.024 & 0.005 & $23.40 e^{-6}$ & $4.27 e^{-6}$ & 6 & 0.004 & 0.001 & $4.83 e^{-6}$ & $1.26 e^{-6}$ \\
\hline 15 & 10 & 0.029 & 0.012 & $29.00 e^{-6}$ & $1.17 e^{-5}$ & 6 & 0.006 & 0.002 & $6.62 e^{-6}$ & $2.08 e^{-6}$ \\
\hline 16 & 10 & 0.043 & 0.014 & $41.10 e^{-6}$ & $1.38 e^{-5}$ & 6 & 0.006 & 0.002 & $5.83 e^{-6}$ & $2.35 e^{-6}$ \\
\hline 17 & 11 & 0.048 & 0.015 & $44.27 e^{-6}$ & $1.38 e^{-5}$ & 6 & 0.006 & 0.002 & $5.67 e^{-6}$ & $1.36 e^{-6}$ \\
\hline 18 & 10 & 0.043 & 0.013 & $39.80 e^{-6}$ & $1.16 e^{-5}$ & 6 & 0.008 & 0.000 & $7.58 e^{-6}$ & $1.16 e^{-6}$ \\
\hline 19 & 12 & 0.052 & 0.18 & $49.50 e^{-6}$ & $1.71 e^{-5}$ & 6 & 0.006 & 0.002 & $6.82 e^{-6}$ & $2.08 e^{-6}$ \\
\hline 20 & 10 & 0.054 & 0.014 & $49.70 e^{-6}$ & $1.27 e^{-5}$ & 6 & 0.006 & 0.002 & $6.30 e^{-6}$ & $1.20 e^{-6}$ \\
\hline
\end{tabular}

$\mathrm{n}$ : Number of specimens; $\delta$ : Standard deviation.

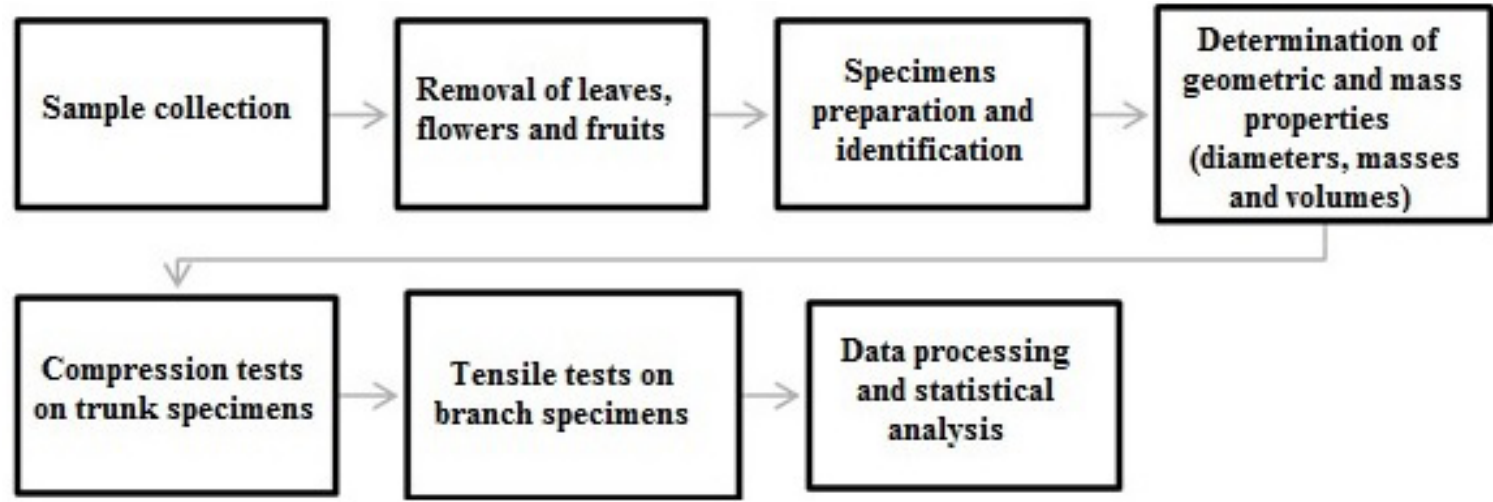

Figure 4: Flowchart of the activities carried out in the field and in the laboratory, from the collection of the samples to the obtaining and analysis of the data extracted in the tests of traction and compression performed in a universal testing machine.

\subsection{Statistical Analysis}

The experiment was conducted in a completely randomized design with 20 samples and one replicate per sample. Each experimental unit consisted of a whole coffee plant. The mechanical property data (elasticity modulus, Poisson's ratio and specific mass) were used to perform a descriptive statistical analysis of the data describing the means, standard deviations, maximum and minimum points, and coefficients of variation. All the statistical analyses were conducted using the $\mathrm{R}$ programming (version 3.4.0) (R Core Team, 2015). 


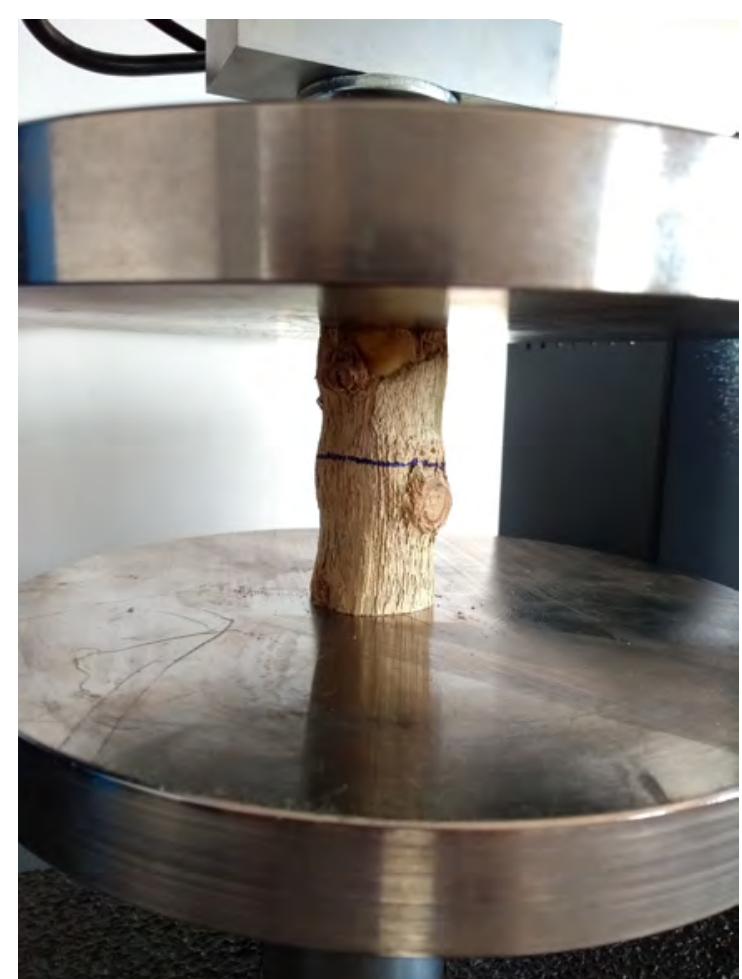

Figure 5: Specimen produced from the trunk of a coffee plant sample being subjected to compression testing, in a universal testing machine, in the direction parallel to the fibers.

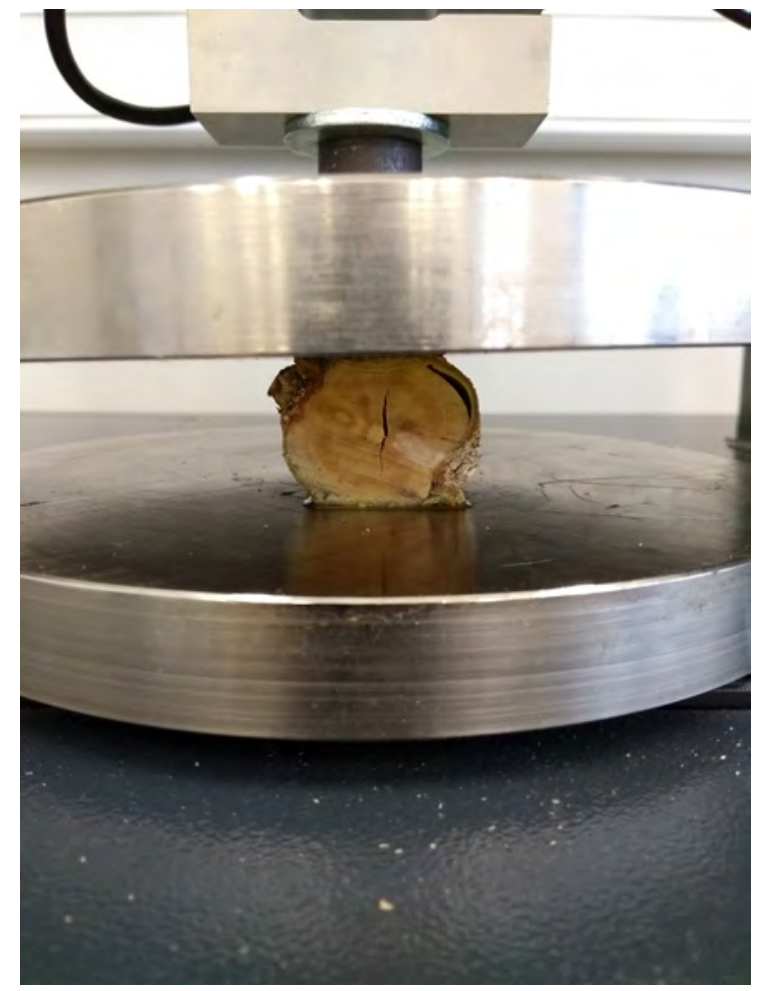

Figure 6: Specimen produced from the stem of a coffee plant sample being subjected to compression testing, in a universal testing machine, in the transversal direction to the fibers.

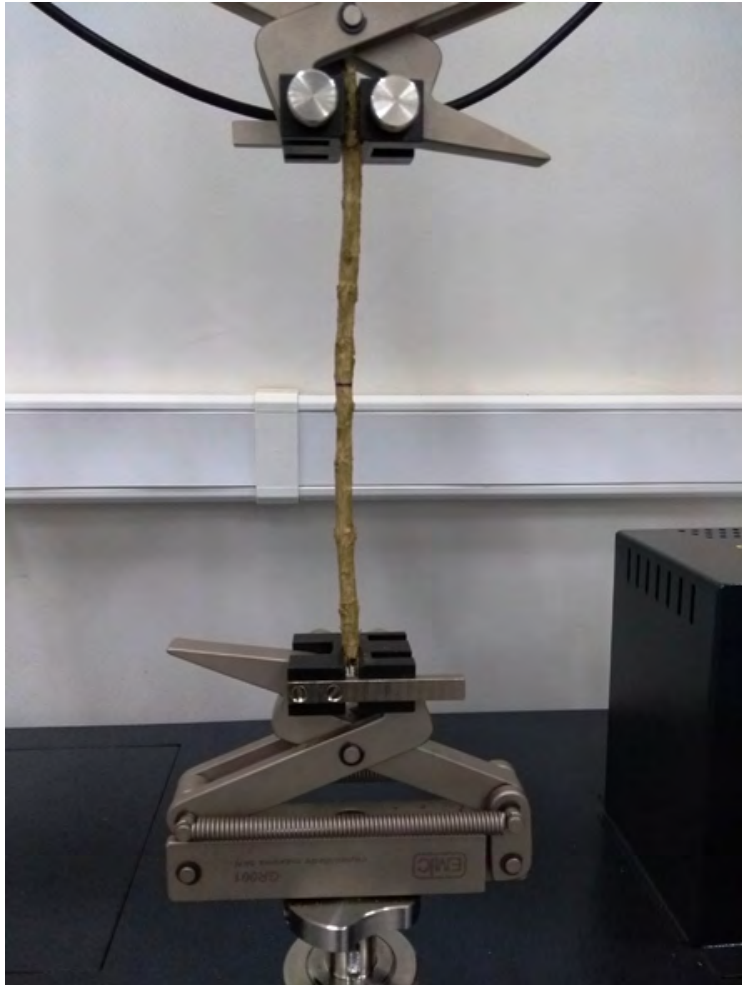

Figure 7: Specimen produced from the branch of a coffee plant sample being subjected to tensile testing, in a universal testing machine, in parallel direction to the fibers.

\section{RESULTS}

The elasticity modulus was determined by the secant line method in compression and tensile tests. For this, the stress and strain data that were extracted from the tests were plotted and their secant was drawn, allowing its calculation, as shown in Figure 8.

The results found for the elasticity modulus for the specimens prepared from the coffee trunks and branches and tested in a universal testing machine are shown in Table 3.

The values obtained for Poisson's ratio in this study are within the reference values for wood (Garcia; Spim; Santos, 2012) and for isotropic materials (Callister Junior, 2007) (Table 4).

The specific mass values found in the present study are above the reference values (Garcia; Spim; Santos, 2012) for other woods used for structural purposes (Table 5).

\section{DISCUSSION}

Christoforo et al. (2013) note that the elasticity modulus is among the most important properties for dimensioning a structure. However, for materials such as wood, the determination of the elasticity modulus is compromised by the great anatomical complexity of the material and the variety that is characteristic of biological materials. In addition, wood has three axes of symmetry, which further complicates the determination of parameters related to its elasticity. 


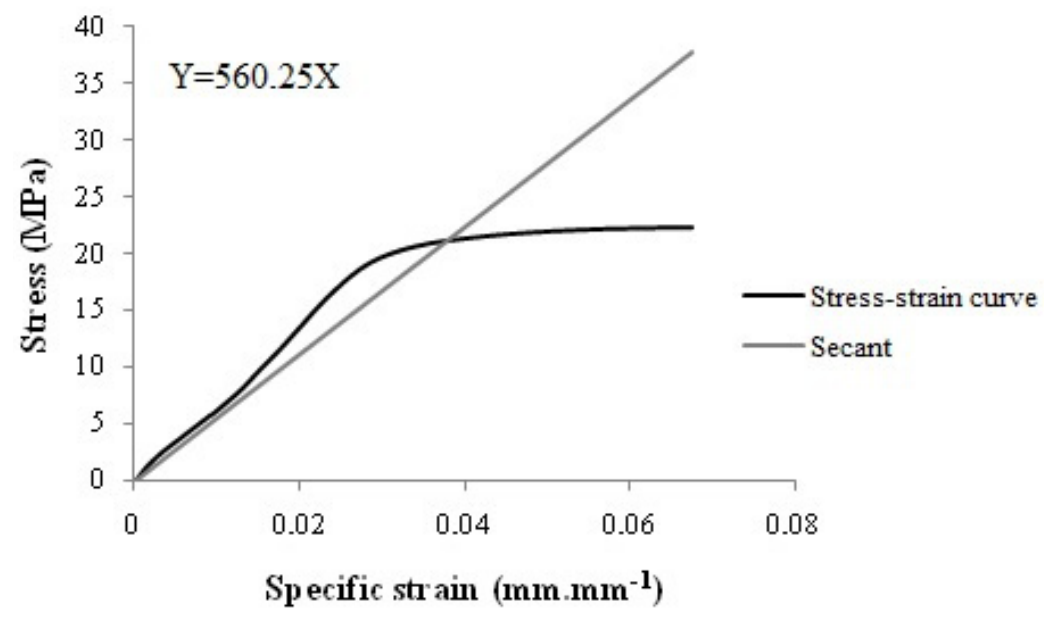

Figure 8: Representation of the stress-strain curve and its secant, obtained experimentally for a specimen of the trunk of a coffee plant sample, submitted to a compression test, in the direction parallel to the fibers, in a universal testing machine.

Table 3: Values of the elasticity modulus in the longitudinal and cross-sectional directions, found for specimens of trunks and branches of coffee plant samples, which were subjected to compression and tensile tests in a universal testing machine

\begin{tabular}{cccc}
\hline & \multicolumn{2}{c}{ Trunks } & Branches \\
\hline & $\mathbf{E}_{\mathbf{D}}$ & $\mathbf{E}$ & $\mathbf{E}$ \\
\hline Mean (MPa) & 108.60 & 1090.94 & 507.72 \\
Standard Deviation (MPa) & 50.73 & 347.00 & 147.80 \\
Maximum (MPa) & 452.35 & 1992.40 & 1798.20 \\
Minimum (MPa) & 19.10 & 428.52 & 57.20 \\
Coefficient of Variation (\%) & 46.70 & 31.80 & 29.10 \\
\hline
\end{tabular}

$\mathrm{E}$ : Longitudinal elasticity modulus; $\mathrm{E}_{\mathrm{D}}$ : Cross-sectional elasticity modulus.

Table 4: Poisson's ratio values found for specimens of trunks and branches of coffee plant samples, which were submitted to compression and traction tests, in a universal testing machine

\begin{tabular}{ccc}
\hline & Trunks & Branches \\
\hline Mean & 0.25 & 0.09 \\
Standard Deviation & 0.11 & 0.06 \\
Maximum & 0.95 & 0.50 \\
Minimum & 0.02 & 0.01 \\
Coefficient of Variation (\%) & 44.40 & 72.10 \\
\hline
\end{tabular}

The values obtained for the elasticity modulus were lower than the reference values for woods used for structural purposes; for coniferous species, the values range between 3,500 $\mathrm{MPa}$ and 14,500 $\mathrm{MPa}$, and for dicotyledonous species, the values range between 9,500 MPa and 24,500 MPa (Garcia; Spim; Santos, 2012). Stangerlin et al. (2008a) found 13,199 MPa and 16,944 MPa for wood from the juvenile and mature Eucalyptus genus, respectively. For juvenile and mature species of the Pinus genus, the values found were, respectively, 8,739 MPa and 17,866 MPa (Stangerlin et al., 2008a); 8,418 MPa and 13,376 MPa (Ballarin; Nogueira, 2005); and 10,894 $\mathrm{MPa}$ and 16,730 MPa (Ballarin; Palma, 2003). Stangerlin et al. (2008b) found 10,897 MPa for juvenile species of the Araucaria genus, 14,367 MPa for mature plants of a species of the Araucaria genus, $13,570 \mathrm{MPa}$ for juvenile plants of the Patagonula genus and 14,616 MPa for mature plants of the Patagonula genus.

Table 5: Specific mass values found for specimens of trunks and branches of coffee plant samples, which were calculated from the relationship between their masses and volumes

\begin{tabular}{ccc}
\hline & Trunks & Branches \\
\hline Mean $\left(\mathrm{kg} . \mathrm{m}^{-3}\right)$ & 1070.05 & 1036.33 \\
Standard Deviation $\left(\mathrm{kg} . \mathrm{m}^{-3}\right)$ & 17.00 & 92.50 \\
Maximum $\left(\mathrm{kg} . \mathrm{m}^{-3}\right)$ & 1140.93 & 2144.97 \\
Minimum $\left(\mathrm{kg} \cdot \mathrm{m}^{-3}\right)$ & 870.98 & 565.78 \\
Coefficient of Variation $(\%)$ & 1.59 & 8.93 \\
\hline
\end{tabular}

Although juvenile wood presents elasticity modulus values lower than those of mature wood, these values are up to 20 times higher than those found in the present study.

The presence of imperfections in the wood may negatively affect its mechanical characteristics; the greater the number of imperfections, such as the presence of nodes, the lower the wood's capacity to withstand stresses. The wood of the coffee trunk in turn has an excessive number of nodes originating from branches inserted into the trunk (Garcia; Spim; Santos, 2012). Thus, coffee wood does not have the necessary characteristics to be used in a structural manner, and its use can be reversed for other purposes, such as for the production of charcoal (Leite et al., 2015). 
Aristizábal, Oliveros and Alvarez (2003), found elasticity modulus values for $4.38 \mathrm{GPa}$; $4.39 \mathrm{GPa}$ and $4.62 \mathrm{GPa}$ (4380 MPa; $4390 \mathrm{MPa}$ and $4620 \mathrm{MPa}$ ) for the medium portions of coffee plant trunks of the varieties Red Colombia, Red Caturra and Yellow Colombia, respectively. For the branches, the values found were 5.19 GPa; 4.48 GPa and 3.39 GPa (5190 $\mathrm{MPa} ; 4480 \mathrm{MPa}$ and $3390 \mathrm{MPa}$ ) for the varieties Red Caturra, Yellow Colombia and Red Colombia, respectively.

Carvalho, Magalhães and Santos (2016) found 2041.5 MPa (standard deviation of 326.1 MPa) for samples of coffee trunk of the Catuaí Vermelho variety, while Coelho et al. (2015) found an elasticity modulus of 1,940 MPa (standard deviation of $662 \mathrm{MPa}$ ) for specimens of coffee branches of the same variety. Both values are above those found in the present study. Differences that may eventually occur are explained by the variations according to age, varieties, climatic conditions and type of management and testing to which the plants were subjected.

The elasticity modulus values can also be influenced by the compression direction during the test. For tests in the longitudinal and cross-sectional directions, respectively, Christoforo et al. (2013) found mean values of 12,003 MPa and 638.43 MPa for plants of the Pinus genus and mean values of 19,065 MPa and 897.86 MPa for plants of the Corymbia genus. This result shows the difference of values in the different directions, and the value found in the cross-sectional direction represents only approximately $5 \%$ of the value found in the longitudinal direction; i.e., the wood tends to withstand more longitudinal compression than cross-sectional compression.

Similar behavior was observed in the values found in this study, in which the cross-sectional elasticity modulus represents approximately $10 \%$ of the value of the longitudinal elasticity modulus, corroborating the results found by Ballarin and Nogueira (2003).

All coefficients of variation observed for the elasticity modulus can be considered very high (Pimentel Gomes, 1987). In general, wood heterogeneity is high among plants, which may affect plants managed under the same management conditions and climate. It is therefore believed that this fact is due to chemical, physical and anatomical variations of the culture (Lobão et al., 2004). As there is no standardization in the manufacture of the specimens, the conduct of the tests may also have contributed to increase the coefficient of variation.

The elasticity modulus and Poisson's ratio are mechanical properties related to the rigidity of the coffee plant structure; thus, variations in these properties certainly cause variations in the determination of their natural frequencies (Garcia; Spim; Santos, 2012).

Carvalho, Magalhães and Santos (2016) found a Poisson's ratio value of 0.37 for specimens from the coffee trunk, and Coelho et al. (2015) found a value of 0.35 for samples of the coffee peduncle, both of the Catuaí Vermelho variety. Tinoco et al. (2014) found Poisson's ratio values of 0.34 for the coffee peduncle at the immature stage and 0.32 at the mature stage; the plants studied were from the Colombia variety. Ballarin and Nogueira (2003) found, for Eucalyptus plants, Poisson's ratio values between 0.013 and 0.70 for tests performed in different directions.

The interval of the Poisson's ratio is very limited, conferring magnitudes to the values found that are very close to the results found in the aforementioned studies.

This was the property with the highest values of coefficient of variation, which are higher than the values considered acceptable for agricultural products (Pimentel Gomes, 1987). The conduction of the tests may have been the factor that influenced the increase in the coefficient of variation.

The specific mass, the elasticity modulus and the Poisson's ratio directly influence the natural frequency of the plant and show an inversely proportional relationship. In addition, numerical simulations are essential parameters for determining the modal properties of a system (Rao, 2008), which can be applied to coffee plants to understand how it vibrates. Knowing your vibration is important to predict what will be your behavior in a fruit harvesting process by mechanical vibrations.

For Eucalyptus plants, Targa et al. (2005) found values of $1,003,000.00 \mathrm{~kg} \cdot \mathrm{m}^{-3}, 624.00 \mathrm{~kg} \cdot \mathrm{m}^{-3}$ and $877.00 \mathrm{~kg} \cdot \mathrm{m}^{-3}$ for the specific mass. Stangerlin et al. (2008a) found very similar values for the same species: $586.00 \mathrm{~kg} \cdot \mathrm{m}^{-3}$ for juvenile wood and $721.00 \mathrm{~kg} . \mathrm{m}^{-3}$ for mature wood. For Pinus plants, Ballarin and Palma (2003) found $674.00 \mathrm{~kg} \cdot \mathrm{m}^{-3}$ for mature wood and $536.00 \mathrm{~kg} \cdot \mathrm{m}^{-3}$ for juvenile wood. Stangerlin et al. (2008a) found $499.00 \mathrm{~kg} \cdot \mathrm{m}^{-3}$ for juvenile wood and $671.00 \mathrm{~kg} \cdot \mathrm{m}^{-3}$ for mature wood. Stangerlin et al. (2008b) also found specific mass for the Patagonula species with values of $743.00 \mathrm{~kg} . \mathrm{m}^{-3}$ and $721.00 \mathrm{~kg} . \mathrm{m}^{-3}$ for juvenile and mature wood, respectively, and for the Araucaria species, they found specific mass values of $519.00 \mathrm{~kg} \cdot \mathrm{m}^{-3}$ and $524.00 \mathrm{~kg} \cdot \mathrm{m}^{-3}$ for juvenile and mature wood, respectively.

As for other properties, the specific mass of juvenile wood tends to be lower than that of mature wood. According to Garcia, Spim and Santos (2012), woods with higher specific mass, in general, has better elastic properties. However, this property alone is insufficient to confer a structural character to the coffee wood.

Carvalho, Magalhães and Santos (2016) found specific mass values of $607.00 \mathrm{~kg} . \mathrm{m}^{-3}$ for coffee trunk samples of the Catuaí Vermelho variety. This value is lower than that found in this study; this variation may be due to the preparation of the specimens used in the two studies.

Aristizábal, Oliveros and Alvarez (2003) found specific mass values of $1123.00 \mathrm{Kg} \cdot \mathrm{m}^{-3} ; 1110.00 \mathrm{~kg} \cdot \mathrm{m}^{-3}$ and 1102.00 kg. $\mathrm{m}^{-3}$ for coffee plant trunks of the varieties Red Caturra, Red 
Colombia, and Yellow Colombia, respectively. Coelho et al. (2015) found values of $900.00 \mathrm{~kg} \cdot \mathrm{m}^{-3}$ for the specific mass of coffee branches of the Catuaí Vermelho variety. For the same variety, Santos et al. (2015) found values of 1,200.00 kg.m , $1,100.00 \mathrm{~kg} \cdot \mathrm{m}^{-3}$ and 1,090.00 kg.m ${ }^{-3}$ for fruits at different maturation stages. These values corroborate the results found in the present study.

Lobão et al. (2004) found in their study that specific mass is minimally related to the elasticity modulus of wood and, consequently, to its mechanical properties. For heavy wood, the authors found a specific mass equal to $880.00 \mathrm{~kg} . \mathrm{m}^{-}$ ${ }^{3}$, which corresponds to an elasticity modulus of 19,479 MPa, and for light wood, they found a specific mass of $575.00 \mathrm{~kg} \cdot \mathrm{m}^{-3}$ and an elasticity modulus of $18,412 \mathrm{MPa}$; this establishes a relationship between the two properties. The authors also noted that lower specific mass indicate lower mechanical strength of wood, which is consistent with the results found in the present study, in which the specimens from the branches had lower specific mass than the specimens from the trunks.

According to Trendelenburg and Mayer-Wegelin (1956), in the case of wood, the specific mass variation is attributed to environmental and management factors, not only to the genus, and the coefficient of variation values can reach up to $30 \%$. Thus, the values observed for the coefficient of variation of the specific mass in this study are within acceptable limits.

The results of this work can provide a better understanding of the mechanical properties of the coffee plants. The determined properties, linked to representative geometric models, can validate experiments conducted in the field, assisting in predicting the dynamic behavior of coffee plants under different scenarios and under different loading conditions. Knowledge of the mechanical properties of coffee plants can assist in decision-making for the construction, design and operation of future machines that perform harvesting of coffee fruits by the mechanical vibration principle.

\section{CONCLUSIONS}

The method used in this study allows the determination of mechanical properties related to the elasticity of coffee trunks and branches, characterizing plants according to their mechanical resistance. These properties help explain the dynamic behavior of the plant under different harvesting mechanisms.

The results obtained indicate the following values:

Elasticity modulus of the trunk, performed from compression tests: $1090.94 \mathrm{MPa}$ in the longitudinal direction and 108.60 MPa in the cross-sectional direction.

Elasticity modulus of the branches, performed from tensile tests in the longitudinal direction: 507.72 MPa.

Poisson's ratio, determined by direct measurements: 0.25 for the trunk and 0.09 for the branches.
Specific mass: $1070.05 \mathrm{~kg} \cdot \mathrm{m}^{-3}$ for the trunk and 1036.33 $\mathrm{kg} \cdot \mathrm{m}^{-3}$ for the branches.

The non-use of different cultivars, crops and maturation stages of coffee plants can be considered a deficiency of this work, however the methodology allowed to obtain its mechanical characterization, and can be used in future works that increase the variability of the samples, to compose a more concise database for coffee growing.

\section{ACKNOWLEDGMENTS}

The authors would like to thank the Fundação de Amparo à Pesquisa do Estado de Minas Gerais (Fapemig), Conselho Nacional de Desenvolvimento Científico e Tecnológico (CNPq) and Coordenação de Aperfeiçoamento de Pessoal de Nível Superior (Capes), for financial support.

\section{REFERENCES}

ARISTIZÁBAL, I. D. T.; OLIVEROS, C. E. T.; ALVAREZ, F. M. Physical and mechanical properties of the coffee tree related to harvest mechanization. Transactions of the ASAE, 46(2):197-204, 2003.

ASSOCIAÇÃO BRASILEIRA DE NORMAS TÉCNICAS - ABNT. Projeto de estruturas de madeira.

Associação Brasileira de Normas Técnicas, NBR 7190, 1997, 107p.

\section{ASSOCIAÇÃO BRASILEIRA DA INDÚSTRIA DE} CAFÉ - ABIC. Tendências do mercado de café.2016. Available in: <http://abic.com.br>. Accessed in: May, 27, 2019.

BALLARIN, A. W.; NOGUEIRA, M. Caracterização elástica da madeira de Eucalyptuscitriodora. Cerne, 9(1):066080, 2003.

BALLARIN, A. W.; NOGUEIRA, M. Determinação do módulo de elasticidade da madeira juvenil e adulta de Pinus taeda por ultra-som. Engenharia Agrícola, 25(1):19-28, 2005.

BALLARIN, A. W.; PALMA, K. A. L. Propriedades de resistência e rigidez da madeira juvenil e adulta de Pinus taeda L. Árvore, 27(3):371-380, 2003.

CALLISTER JUNIOR, W. D. Materials science and engineering. 7. ed. New York: John Wiley \& Sons, 2007. 944p.

CARVALHO, E. A.; MAGALHÃES, R. R.; SANTOS, F. L. Geometric modeling of a coffee plant for displacements prediction. Computers and Eletronics in Agriculture, 123(1):57-63, 2016. 
CHRISTOFORO, A. L. et al. Metodologia para o cálculo dos módulos de elasticidade longitudinal e transversal em vigas de madeira de dimensões estruturais. Ciência Rural, 43(4):610-615, 2013.

CIRO, V. H. J. Coffee harvesting I: Determination of the natural frequencies of the fruit stem system in coffee trees. Applied Engineering in Agriculture, 17(4):475479, 2001.

COELHO, A. L. F. et al. Determinação das propriedades geométricas, físicas e mecânicas do sistema frutopedúnculo-ramo do cafeeiro. Revista Brasileira de Engenharia Agrícola e Ambiental, 19(3):286-292, 2015.

COSTA, C. A. et al. Propriedades mecânicas e de fluxo de produtos agroindustriais. Revista Brasileira de Engenharia Agrícola e Ambiental, 18(7):774-780, 2014.

FUNDAÇÃO JOÃO PINHEIRO - FJP. A produção de café em Minas Gerais: Desafios para a industrialização. Diretoria de Estatísticas e Informações, n. 14, 2018. 69p.

GARCIA, A.; SPIM, J. A.; SANTOS, C. A. Ensaios dos materiais. 2. ed. Rio de Janeiro: LTC, 2012. 384p.

GRUPIONI, C. M. F. et al. Development and evaluation of operational performance of macaw fruits semi-mechanized harvester by means mechanical vibrations principle. Semina: Ciências Agrárias, 39(2):497-510, 2018.

LEITE, E. R. S. et al. Qualidade do carvão vegetal produzido a partir da madeira do cafeeiro, para uso bioenergético. Coffee Science, 10(2):251-261, 2015.

LOBÃO, M. S. et al. Caracterização das propriedades físico-mecânicas da madeira de eucalipto com diferentes densidades. Árvore, 28(6):889-894, 2004.

OLIVEIRA, Z. R. C. R. et al. Mechanical properties of the rachis from macaw palm bunches. Acta ScientiarumAgronomy, 40(1):1-7, 2018.

ORGANIZAÇÃO INTERNACIONAL DO CAFÉ - OIC. Relatório sobre o mercado de cafeeiro. 2019. Available in: <http://consorciopesquisacafe.com.br>Accessed in: May, 27, 2019.

PIMENTEL GOMES, F. A estatística moderna na pesquisa agropecuária. 3. ed. Piracicaba: Potafos, 1987. 162p.
R CORE TEAM. R: A language and environment for statistical computing. 2017. R Foundation for Statistical Computing, Vienna, Austria. Available in: <https:// www.R-project.org/>. Access in: March, 20, 2020.

RAO, S. Vibrações mecânicas. 4. ed. São Paulo: Pearson, 2008. 448p.

SANTOS, F. L. et al. Simulation of the dynamic behavior of the coffee fruit-stem system using finite element method. ActaScientiarum Technology, 37(1):11-17, 2015.

SOUZA, V. H. S. et al. Evaluation of the interaction between a harvester rod and a coffee branch based on finite element analysis. Computers and Electronics in Agriculture, 150(1):476-483, 2018.

STANGERLIN, D. M. et al. Determinação do módulo de elasticidade em madeiras por meio de métodos destrutivo e não-destrutivo. Revista Brasileira de Ciências Agrárias, 3(2):145-150, 2008a.

STANGERLIN, D. M. et al. Obtenção do módulo de elasticidade em madeiras de Patagonula americana e Araucariaangustifolia por meio do método ultra-sonoro. Revista Científica Eletrônica de Engenharia Florestal, 1(11):1-15, 2008b.

TARGA, L. A. et al. Avaliação do módulo de elasticidade da madeira com uso de método não-destrutivo de vibração transversal. EngenhariaAgrícola, 25(2):291299, 2005.

TRENDELENBURG, R.; MAYER-WEGELIN, H. Das holzalsrohstoff. 2. ed. Munchen: Carl HanserVerlag, 1956. 541p.

TINOCO, H. A. et al. Finite element modal analysis of the fruit-peduncle of Coffeaarabica L . var. Colombia estimating its geometrical and mechanical properties. Computers and Electronics in Agriculture, 108(1):1727, 2014.

VELLOSO, N. S. et al. Mechanical properties of the macaw palm fruit-rachilla system. Pesquisa Agropecuária Tropical, 47(2):218-225, 2017.

VILLAR, F. M. M. et al. Elasticity modulus and damping ratio of macaw palms rachillas. Ciência Rural, 47(2):1-6, 2017. 